\title{
THE GROWING REALITY OF LEGAL RIGHTS FOR COMPANION ANIMALS
}

\author{
DAVID FAVRE ${ }^{1}$ \\ ${ }^{1}$ Michigan State University, College of Law, 648 N. Shaw Lane Rm 361, East Lansing, MI 48824-1300, \\ USA. ORCID: 0000-0001-9947-9020, Email: favre@law.msu.edu
}

ABSTRACT: Over the past decade, the fifty state legislatures of the United States have been adopting legislation for the benefit of the group of animals known as companion animals (pets). When considered together as a set, these laws create an initial set of legal rights for that group of animals. To explore that conclusion, the definition of a legal right and the particular statutes, such as new divorce laws, are considered.

KEYWORDS: animal rights, animal interest, companion animals, victims, trust, divorce

\section{INTRODUCTION}

Many of the articles in this esteemed publication use the phrase "animal rights". Nearly everyone writing for this publication and reading the articles are in favor of animal rights. However, my forty years of experience in this field suggest that most people do not actually know what the phrase means in the world of law, or how the animals will get them, or how it would affect specific animals.

In the European Union and other civil law countries considerable energy has been spent in establishing, as a first order of action, the creation of a new legal category for animals (Giménez-Candela 2018:28-47). While this is all very good, it does not by itself create any new legal rights in animals. In the U.S. we have the valiant efforts of the Nonhuman Rights Project seeking to establish that a chimpanzee or elephant is a legal person under the common law cause of action known as habeas corpus. However, to date, it has not been fully successful ${ }^{1}$.

One key misperception held by many is that a set of "rights" will be granted to all animals in one sweeping statement of legislation. This is actually highly unlikely. The

\footnotetext{
${ }^{1}$ Nonhuman Rights Project, Inc., on Behalf of Tommy, v. Lavery, 124 A.D.3d 148 (S. Ct, 3rd Dept. NY, 2014); Matter of Nonhuman Rights Project, Inc. v Lavery, 31 N.Y.3d 1054, 100 N.E.3d 846 (2018).
} 
world is too complex with too many human economic and cultural issues in conflict to resolve all the animal issues with one law. The nature of our law creation process is piecemeal, by topic. Legal rights arise for various communities or species of animals. Those in commercial food facilities are treated differently from those who live with us, and from those used in entertainment. For the following discussion, the focus will be solely on "Companion Animals", as they are the group of animals who presently are receiving legal rights in the United States. Their presence and importance in the core of the family is now recognized by various legislatures (for full discussion of the science of the importance of companion animals to the humans who have them, see Favre and Dickinson 2017).

When discussing animals in the legal context, it is often suggested that animals are property, things, and thus cannot be legal persons; that is, they do not possess that legal characteristics known as personhood (Personhood does not refer to individual humans, but to those entities that have legal rights within our system, such as cities and corporations). This is a false dichotomy, suggesting that if you are a thing, property, you cannot hold a legal right. While this has been true historically, it is not true today. Some animals, in some countries, are accumulating some legal rights. It is only the lack of legal imagination that limits the acknowledgment that some dogs in the United States presently possess a few legal rights. To acknowledge this possibility requires the dismissal of the precept that property cannot have legal rights. Rights may be allocated to property if deemed appropriate by the lawmakers of that society ${ }^{2}$. Companion animals may be owned by humans, but nevertheless, possess legal rights assertible within the legal system. The presence of dogs within the intimate family is the driver of this new political and legal reality. Of course, cats are also important within a family, but dogs seem to be the driving species.

The line between property and legal rights holders has always been a bit fuzzy (law not philosophy). Human beings themselves have wanders over and back across that line. What is often forgotten today is that humans have often been considered property and yet also have limited rights. In the historical common law system, wives, as well as children, were considered the property of the husband. It has taken centuries for women to become the legal equal of men. For example, receiving the right to hold title to property, or vote, or the right to be a lawyer, or to be admitted into major public universities. While it is no longer the case that children are considered the property of the parents, there is still great discretion, power, that the parent has over the child. The legal rights of a human fetus are clearly at issue today (Walen 2005).

The prior examples all involved human beings, and the reach over the property line to bring in non-human animals into the circle of legal right holders is a wider step. However, it is not impossible. This is because, like all humans, all animals (drawing a line at vertebrate animals for this discussion) have "interests" which can come into conflict with human interests. The interests include: access to food and water, the ability to exercise the genetically provided capabilities of an animal (wings, claws and

\footnotetext{
${ }^{2}$ In 2014 New Zealand signed a treaty with the Maori people that recognized that the Whanganui river has the rights of a legal person (Boyd 2017, chap. 8).
} 
sense of smell, for example), to reproduce, and of course, to live, which requires a place to live.

It will be the case that claims for animals' rights will conflict with the interests of some humans. Is it not the purpose of the legal system to resolve conflicting interests? (Pound 1959: 103) While these conflicts in interests have always existed, it is in today's small family environment, combined with a more elastic definition of family, that society is giving more weight to the animal interests, particularly companion animals. For companion animals, the transition from mere personal property to living property (Favre 2010), with a status more like children, is underway.

Before considering the specific examples set out below, there must be a clear context by which to judge presence of a legal right. Rights in the world of philosophy are part of an eternal debate, opinions tossed back and forth and there is no ultimate decider of who is right about rights. For the law there is the reality of the judge who must say yes or no; there is an appropriate claim of legal rights before the court or there is not. The judge makes two different judgements. First, is the 'being' knocking on the door of the courtroom capable of holding any rights? Assuming the first is satisfied, then the second question is whether the being before the court possesses the right asserted. In a 2018 federal case, the 9th Cir. Court of Appeals (a court just below the U.S. Supreme Court) held that while the macaque Naruto had the capacity to hold a legal right, the federal Copyright Act did not extend the legal protections of the Act to primates $^{3}$.

\section{ANIMALS AS VICTIMS OF CRIMES}

As with all areas of law, animals are initially, historically, seen as property. One recent case suggests that the status of animals within the criminal legal system are moving into a new phase. This deals with a fundamental conceptual view of what is an animal, simple property or individuals, acknowledged as such. For example, if someone breaks into a home, and destroyed some furniture and perhaps a computer, the personal property is lumped together, and it would be considered one crime for purposes of sentencing a guilty defendant. In 2018, the Oregon Supreme Court had the issue come before them in the context of the sentencing a defendant, where the state wanted 11 counts of violation of the cruelty law, one count for each animal that has been harmed by the defendant ${ }^{4}$. The defendant claimed the actions merited only one count and therefore he should receive a lesser sentence of jail time. The Court held that each animal was a victim and therefore that the charge of eleven counts was correct. This is the first time a high court has allowed an animal the status of a victim in the context of human criminal law.

\section{REPRESENTATION}

On the other side of the country, another new step exists for dogs and cats caught

\footnotetext{
${ }^{3}$ Naruto v. Slater, 888 F. $3^{\text {rd }} 418$ ( $9^{\text {th }}$ Cir. 2018).

${ }^{4}$ Oregon v. Crow, 294 Or. App. 88 (2018).
} 
up in criminal proceeding against human actors. It is now customary to provide an opportunity for the human victim of a crime to have a voice in the proceedings, particularly at the sentencing stage. What happens when the victim is an animal? For dogs and cats, being members of that special class of companion animals, this is now happening in the state of Connecticut. Under a 2017 law, ${ }^{5}$ the court may appoint an attorney or a law student to aid the court in a criminal anti-cruelty proceeding. Law students at the University of Connecticut are actively taking advantage of this power and being appointed to help in a number of cases.

\section{EXTRA PROTECTION FOR COMPANION ANIMALS}

The legal system has long provided protection for animals against intentional acts of cruelty and the unnecessary infliction of pain and suffering. The introduction of aggravated animal cruelty legislation has been among the more significant recent changes. The State of Illinois, for instance, adopted a special provision under the title Aggravated Cruelty as follows: 'No person may intentionally commit an act that causes a companion animal to suffer serious injury or death'6. Liability under general animal cruelty law provisions are usually qualified by or conditioned on various factors such as 'unnecessary', 'knowingly' and 'cruelly'. The language from the Illinois statute is, however, without qualification. Therefore, if, while driving a car in Illinois, a person intentionally runs over a cat or, alternatively, a raccoon, both acts would be a crime. However, hitting the cat would be a much more serious crime ${ }^{7}$.

\section{ANIMAL ABUSER REGISTRY}

Another example of the criminal law providing increasing consideration to the importance of animals is the creation of an Animal Abuser Registry. These state registries parallel the registries for those who have been convicted of sex abuse crimes. For example, see the provision from the Tennessee Animal Abuser Registration Act adopted by Tennessee in $2015^{8}$. The Registry is a public internet database with the name, addresses and animal crimes of defendants ${ }^{9}$.

\section{TRUST AND WILL}

It is now accepted in all fifty U.S. States that pet trust, the setting aside a sum of cash for the care of companion animals, can be created in a personal will or as a freestanding trust ${ }^{10}$. Again, the pet is in almost the same legal status as that of a child. The courts have the power to force the trustee to abide by the conditions of the trust for the benefit of the animals named in the trust.

\footnotetext{
${ }^{5}$ Conn. G. Stat. Anno. § 54-86n.

${ }^{6} 510$ Ill. Comp. Stat. 70 \$3.02(a).

${ }^{7}$ Also see, Tenn. Code Ann. §39-14-212.

${ }^{8}$ Tenn. Code Ann. Sec. 40-39-103.

${ }^{9}$ See: https://www.tn.gov/tbi/tennessee-animal-abuse-registry.html.

${ }^{10}$ Unif. Trust Code § 408, UnIF. LaW Comm’n 2000.
} 


\section{COMPANION ANIMALS IN HOT CARS}

In 2018 Louisiana enacted a law that grants immunity to Good Samaritans who forcibly enter a motor vehicle to save minors (children), or dogs and cats in distress ${ }^{11}$. Under Louisiana law, there is no liability on the part of a person for property damage or trespass to a motor vehicle, if the damage is caused while the person was rescuing a minor or an animal in distress. Note that nearly identical statutory language exists for both human children, and dogs and cats. Over a dozen states have passes such laws ${ }^{12}$.

\section{RESTRAINING ORDERS}

Companion animals have legal visibility when the courts' grant personal restraining orders, normally to protect one spouse from confronting the other. In the fall of 2016, the State of Alaska modified existing divorce law to allow victims of domestic violence to seek an order for protection of property including “a pet, regardless of ... ownership"13. The new provisions also allow a court, in the context of a protection order request, to order the payment of funds by the named party for not only support for the adult victim and minor children, but, also for pets in the care of the petitioner ${ }^{14}$. In this context, a companion animal receives protections similar to those of a child. By the end of 2016, thirty-two states had protective order provisions that included animals (Wisch 2019).

\section{DIVORCE}

Until 2017, in all fifty states, the divorce laws did not distinguish a dog or cat from other personal property during the judicial division of property. In that year, Alaska was the first state to adopt a new provision for companion animals, followed shortly thereafter by Illinois and California. The Alaska law allows the relevant court to make specific provision in a final divorce judgment: "for the ownership or joint ownership of the animal, taking into consideration the well-being of the animal (Emphasis added.)"15. This statute clearly acknowledges that animals have interests independent of those of the spouses and that those interests deserve consideration by the legal system when a divorce proceeding impacts the animal. In 2019, New Hampshire adopted a law with slightly different language: "taking into consideration the animals' wellbeing" ${ }^{16}$. Note that exactly which interest of the companion animal, and how to weigh the interests,

\footnotetext{
${ }^{11}$ http://www.legis.la.gov/legis/ViewDocument.aspx?d=1101104.

${ }^{12}$ For more detailed information on these laws, please visit the comparative law table on the topic at https://www.animallaw.info/topic/table-state-laws-protect-animals-left-parked-vehicles.

${ }^{13}$ Alaska Stat. §18.66.100(c)(10) 2016.

${ }^{14}$ Alaska Stat. §18.66.100(c)(12) (2016).

${ }^{15}$ Alaska Stat. \$25.24.160(a)(5) (2016). Also see, 750 Illinois Codified Stat. 5/501 - 503; Calif. Family Code $§ 2605$.

${ }^{16}$ State Of New Hampshire, "An Act relative to property settlement including animals." HB 3612019 SESSION (19-0820).
} 
are not provided for in any of these statutes. No cases have been decided under any of these new laws.

\section{REMOVAL OF AN ANIMAL FROM A HOME}

Another parallel between the legal protection of companion animals and children manifests when the state seeks the removal of the animal from the household to protect the animal from the risk of future harm. If the owner of an animal is charged with a criminal violation of state anti-cruelty law, perhaps beating an animal or failing to provide adequate care for an animal, then even before the criminal charges are decided, the state may seek the removal of the animal from the defendant's control with a forfeiture action ${ }^{17}$.

\section{JOINING THE FAMILY ON A DINNER NIGHT OUT}

In 2018, Ohio joined 10 other states that have laws allowing restaurants to maintain 'dog friendly' patios ${ }^{18}$. The new law provides a "retail food establishment or food service operation" the ability to allow dogs in outdoor dining areas provided they met some modest requirements. These laws suggest, again, that the public is increasing accepting that companion animals are part of the intimate family, and that they be extended the privileges joining their family when the humans are out on the town for dinner.

\section{CONCLUSION}

All of the above legislation occurred without anyone mentioning 'animal rights', rather, it was the perceived as right thing to do by the elected legislators, to protect and acknowledge these new important members of the human family. These quiet steps forward have arisen in the naturally political process of the States of the United States. Humans with concerns about the companion animals they live with convince legislators to do the right thing. If you want to obtain legal rights for animals, a strong focus on family and criminal law is the place to start. Being property while having a presence in the legal system is clearly possible. The question for the future is how far this should go, and when and how will it apply to other categories of animals.

FUNDING: This research received no external funding.

CONFLICT OF INTEREST: The author declares no conflict of interest.

\section{REFERENCES}

Boyd, David R. 2017. The Rights of Nature: A Legal Revolution that Could Save the World. Toronto, ON: ECW Press.

\footnotetext{
${ }^{17}$ For example, see Mich. Comp. Laws Anno. § 750.50(3).

${ }^{18}$ The bill amends section 3717.05 of the Ohio code and enacts section 3717.14 of the Revised Code.
} 
Favre, David. 2010. "Living Property: A New Status for Animals Within the Legal System.” Marquette Law Review 93(3): 1021-1070.

Favre, David and Thomas Dickinson. 2017. "Animal Consortium.” Tennessee Law Review 84: 839-932. Retrieved September 10, 2019 (https://digitalcommons.law. msu.edu/cgi/viewcontent.cgi?article=1623\&context=facpubs).

Giménez-Candela, Marita. 2018. "The De-Objectification of Animals in the Spanish Civil Code." dA.Derecho Animal (Forum of Animal Law Studies) 9(3): 28-47.

Pound, Roscoe. 1959. Jurisprudence. Vol. 3. St. Paul, Minn.: West Publishing Co.

Walen, Alec. 2005. "The Constitutionality of States Extending Personhood to the Unborn.” Constitutional Commentary 22:161-179. Retrieved September 10, 2019 (https://scholarship.law.umn.edu/cgi/viewcontent.cgi?article=1062\&contex$\mathrm{t}=$ concomm).

Wisch, Rebecca F. 2019. “Domestic Violence and Pets: List of States that Include Pets in Protection Orders.” Animal Legal \& Historical Center. Retrieved September 10, 2019 (https://www.animallaw.info/article/domestic-violence-and-pets-liststates-include-pets-protection-orders).

\section{BIOGRAPHICAL NOTE}

David Favre is professor of law at Michigan State University College of Law, the US.

OPEN ACCESS: This article is distributed under the terms of the Creative Commons Attribution Non-commercial License (CC BY-NC 4.0) which permits any non-commercial use, and reproduction in any medium, provided the original author(s) and source are credited. 
